\title{
TOURISM POTENTIAL OF NEGLECTED SMALL RURAL AREAS
}

DOI: http://dx.doi.org/10.18509/GBP.2020.80

UDC: 332.14.055.2:338.48]:303.442(497.7-17)

\section{Biljana Petrevska \\ Nikola Dimitrov}

Faculty of Tourism and Business Logistics, Goce Delčev University - Štip, North Macedonia

\begin{abstract}
Rural areas, particularly small villages, often provide interesting and almost forgotten aspects for own and regional development. On the other side, they struggle with many negative profound impacts in terms of depopulation, aging and migration, along with economic depression and poor agricultural activity, causing inevitable change on their further development. This study illustrates three villages in the Vardar region of North Macedonia (Nežilovo, Oreše and Papradište) being identified as particularly vulnerable to already noted processes. Based on a first-hand experience and data collected from a field research, the sampled villages are evaluated as locations with high tourism potential. Upon a rapid assessment, it was found that selected rural areas may find compatible and prospective economic activity that may encourage diversification of rural activities. In this line, the paper suggests that rural tourism may boost the local economy and prevent rural areas to be neglected. It is concluded that rural tourism should be considered as a long-term solution for preventing further abandonment and to encourage the vitality of sparsely populated rural areas.
\end{abstract}

Keywords: Rural transformation; Tourism development; Rural potential; North Macedonia.

\section{INTRODUCTION}

Rural areas are faced with numerous challenges related to their future existence due to global economic changes. So, rural economy is facing the need for alternatives in overcoming many conditions, like: low production, poor agricultural incomes, rural abandonment, unemployment, increase in poverty levels, environmental pollution, etc. Moreover, the extremely high level of depopulation has particularly eroded the vitality of villages and rural communities.

Among the most profound problems for small rural areas in North Macedonia, is the mass migration towards cities. It started almost parallel with urbanization and industrialization process, just after the World War II, reaching its peak by the end of 1970s. The industrial collapse in the 1990s returned to villages only small number of those who struggled for bare existence, forcing them to focus on small-scale agriculture and cattle breading. Practically, no young population returned or stayed in the villages transforming them into economically drained rural areas. So, the redistribution of population in North Macedonia is still an ongoing process, with inevitable consequences for the small villages, the agricultural production and the vitality of population including the quality of living. Therefore, tourism is detected as a way out in providing additional financial input for rural households. 
The study discusses the possibility for introducing tourism as an alternative for sustainable rural economies in three selected villages in the Vardar region of North Macedonia (Nežilovo, Oreše and Papradište). These villages are identified as particularly vulnerable rural areas in terms of a depopulation trend. The paper argues that they possess tourism potential to use and enhance the existing resources, provide some economic effects, inject capital and motivate the locals, as a way out to be saved from disappearing. The paper is structured in several parts. After the introduction, section two presents a brief overview of literature concerning the concept of rural tourism development. This is followed by the research methodology, along with the main findings and discussion. The overall conclusion is presented in the last section. Furthermore, the study contributes to the literature review on rural tourism in North Macedonia, in addition to some previous findings [4], [5], [25-27].

\section{LITERATURE REVIEW}

Rural tourism becomes a global trend that is constantly growing faster than traditional mass tourism, with expectations to gain $20 \%$ share of the European tourism market in the next 20 years [11], [21]. So, in the past two decades, tourism is recognized as a potential and favorite tool, but with still unorganized reaction for managing and achieving a development of rural areas in many parts of Europe [33], [34]. On the other hand, its complex nature with a strong interconnectivity between the elements and issues, makes the defining of rural tourism very problematic [2].

A large body of literature elaborates the interconnectivity between the rural areas and tourism development. In this line, [1], [19], [28] and [35] note that rural areas serve as necessary preconditions for creating a tourism product, since resource itself is not a product. Moreover, rurality is the fundamental attraction of the countryside as rural tourism destination [3], [14], [17]. Rural areas are often identified as places for relaxation and escape from the overcrowded and stressful urban life [36], in finding mental peacefulness [18], and pure air [7]. In this line, [38] argues that rural can be approached from different facets: those of spatial practices (rural localities), representations of space (formal representations of the rural) and lived spaces (everyday rural lives). Likewise, the attributes of rural areas are opposite to the urban image, and give the most 'authentic' nature, food (wild food, countryside food, and traditional food), peace and quiet, safety, freedom, uncrowdedness, non-violence, traditions and cultural experiences [24].

Rural areas often build tourism due to the existence of local amenities like historical sites, natural beauty and clean air [8]. To that [13] and [20] add cultural traditions and values, while [37] and [23] additionally include family patterns, folklore, social customs, museums, monuments, historical structures and landmarks. So, rurality is the fundamental attraction of the countryside as a rural tourism destination [14]. On the other hand, the small scale tourism becomes an important activity often promoting employment, vitality and sustainability of rural areas [12], [16], [29].

\section{METHODOLOGY}

The analysis is based on a qualitative research method, mainly by exploring a conceptual literature review, along with a rapid evaluation of selected rural areas. The data is collected from a field research conducted in September 2019 by applying a communitybased research and evaluation (CBRE) approach, as an action research approach [30]. The CBRE enables to collect data by jointly discussing community-related issues with 
local residents. A first-hand data is collected through observations and many informal interviews and discussions with local community members.

Nežilovo, Oreše and Papradište are three small, depopulated and economically depressed villages, being selected for an in-depth analysis. They belong to the municipality of Čaška in the Vardar region of North Macedonia (Figure 1). More precisely, the main criteria for their sampling were:

- Being a small village in terms of the number of local inhabitants, and being faced with the problems of aging, productivity, poverty along with some strong migration and depopulation processes;

- Having attractions in the rural environment and a resource base (already attractive tourist center) in the area of $10-20 \mathrm{~km}$ with good connectivity to an urban center;

- Self-providing accommodation or at least in the near-by vicinity; and

- Having a potential for practicing activities in a traditional way in a direct contact with the nature and offering participation into the life of the rural population.

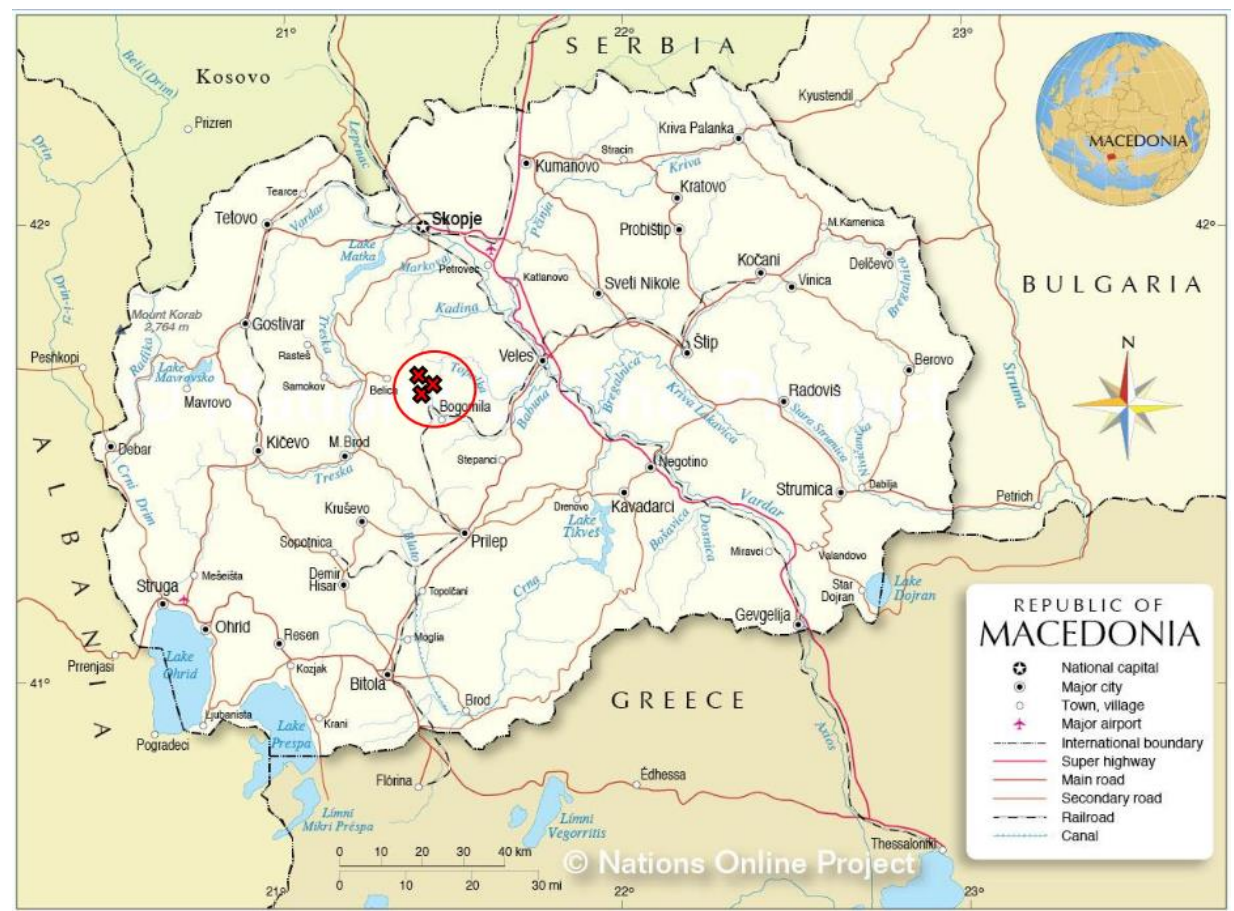

Figure 1. Location of sampled villages (Nežilovo, Oreše and Papradište) in North Macedonia Source: [22]

\section{FINDINGS AND DISCUSSION}

Table 1 presents data on population of Nežilovo, Oreše and Papradište. The data are obtained from secondary sources (literature review and official censuses), and primary sources (field survey assessment). The censuses were carried out in 1948, 1961, 1994 and 2002 according to unified methodologies and forms for all census areas.

As of Table 1 it is noticeable that selected villages are struggling demographically to survive. During 1948-2019, a population decline is present, pointing that the villages suffered an enormous out-migration leading to almost total depopulation. The last column of Table 1 presents the exponential growth rate showing that the sampled villages note a lost between $3-5 \%$ of its population each year leading to constant depopulation over 7 
decades. This means that these, and many similar small villages throughout North Macedonia, are highly depressed and depopulated and almost wiped off the map.

Table 1. Population in Nežilovo, Oreše and Papradište (North Macedonia)

\begin{tabular}{lcccrrrrr}
\hline \multirow{2}{*}{ Village } & \multicolumn{9}{c}{ Years } & Population decline \\
\cline { 2 - 8 } & $1900^{1}$ & $1948^{2}$ & $1961^{2}$ & $1994^{2}$ & $2002^{2}$ & $2019^{3}$ & (\%) 1948-2019 \\
\hline Nežilovo (Figure 2) & 470 & 319 & 333 & 82 & 63 & 30 & -3.27 \\
\hline Oreše (Figure 3) & 460 & 796 & 871 & 296 & 202 & 40 & -4.12 \\
\hline Papradište (Figure 4) & 420 & 612 & 716 & 4 & 7 & 15 & -5.09 \\
\hline
\end{tabular}

Source: ${ }^{1}[15] ;{ }^{2}[32] ;{ }^{3}$ Authors' evaluation based upon a field-research.
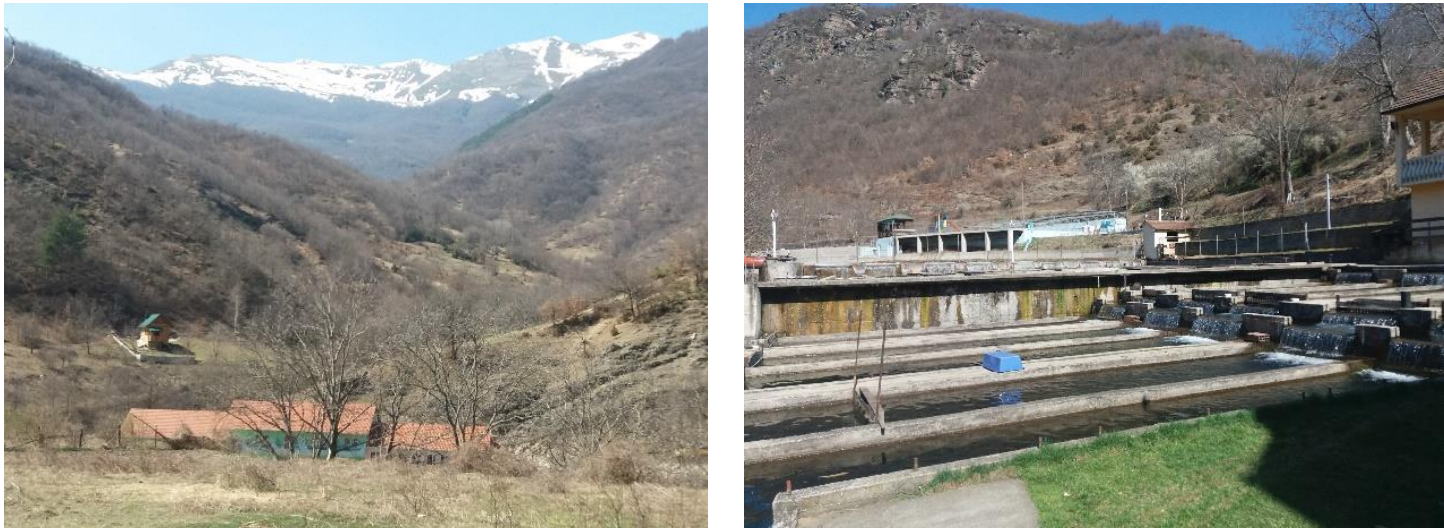

Figure 2. Scenery of Nežilovo, North Macedonia Source: Authors'

As of Table 1 one may conclude the presence of heavy impacts of negative processes, like the rural-urban migration patterns in particular. Along with the expansion of the industrial production, urban centers dramatically emerged, thus attracting the low educated rural population from the villages. Very slowly but gradually the mind-set of the villagers who immigrated to the cities, has transformed by adapting to the urban life style. At the same time, by raising the educational levels, young people continued to leave small communities and migrate to big cities in order to find proper employment. So, redistribution of the population was, and still is, an ongoing process. This resulted with inevitable consequences for the small villages, the agricultural production and rural economy, the vitality of population and the quality and culture of living.


Figure 3. Scenery of Oreše, North Macedonia Source: Authors' 
Based on the field research, it was found that the selected villages offer various activities that could be further developed as tourism products and sustainable practices. In this line, they may identify specific rural activity packages (for example, to walk in the nature trails and pick berries, engage in a cattle breading process and experience a forest therapy, etc.) and design services and promotions. At the same time, it was detected that the evaluated villages represent a complex pattern of rural environment, economy and tradition, where the local community has the possibility to use a high share of tourism revenues, thus contributing to the local economic development.
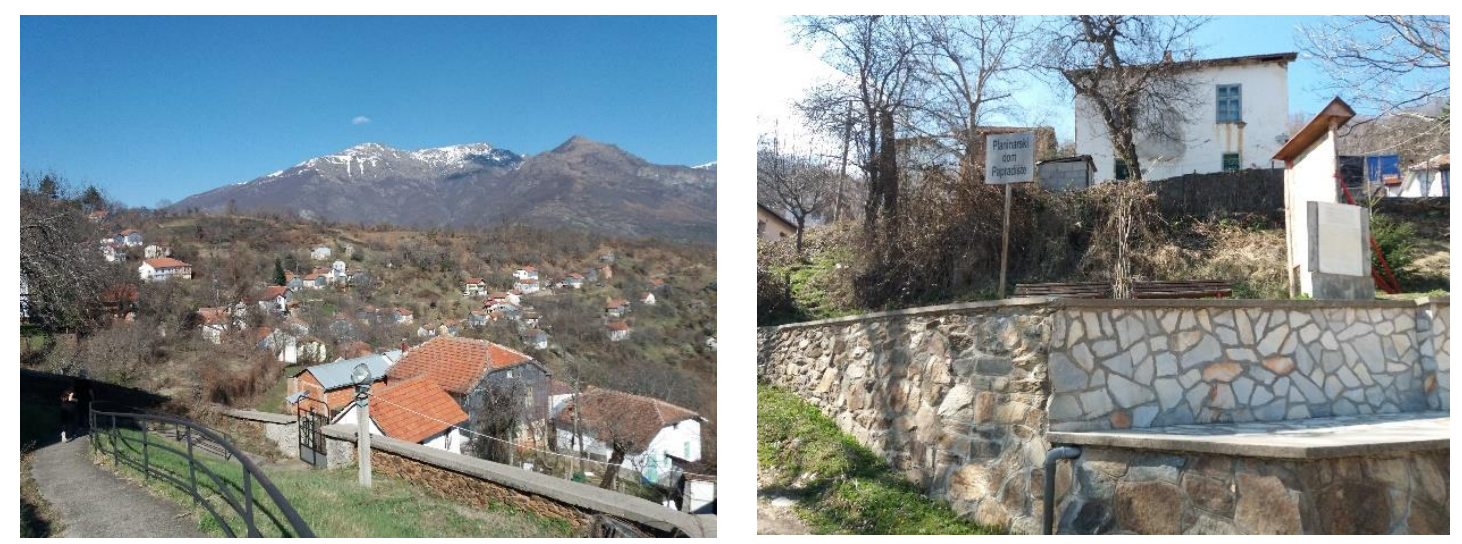

Figure 4. Scenery of Papradište, North Macedonia Source: Authors'

The evaluated rural areas have a wide range of opportunities to be profiled as an attractive and authentic destinations among tourists and travellers. Namely, it was found that they have core elements for developing a small scale rural tourism. They all: possess attractions and accommodation in a rural environment, provide a personalized contact, allow practicing activities in a traditional way in a direct contact with the nature and offer a "life practising technique" (participating in the life of the local rural inhabitants). So, if tourism is supported in these villages, it may provoke numerous positive impulses particularly in terms of diversifying the local economy, providing a new source of income for the local farmers, introducing a new form of destination resilience and encouraging some new forms of businesses.

On the other side, it was evaluated that sampled villages are challenged by many general weaknesses which have severe negative impacts on their development. They are faced with: a constant rapid decrease in the size of population; an unfavourable age structure; small and old households; an unfavourable educational structure; lethargy; a lack of awareness; a lack of finance; etc. It is assessed that various potential threats may act as additional barriers for initiating and supporting rural tourism development, like: neglecting the traditions; degradation of the natural and anthropogenic surrounding; fear of a new way of thinking and acting; etc. Furthermore, these small villages, and many more similar in North Macedonia, are lacking many core and supporting amenities for tourism development, like: infrastructure, accommodation, private sector initiative, training on positive effects of rural tourism, along with raising awareness of locals on the preservation of the natural, anthropogenic and cultural values. 


\section{CONCLUSION}

The study describes the main ambient and general characteristics of three selected rural areas ((Nežilovo, Oreše and Papradište) in North Macedonia. These villages, as many other in the country, are greatly influenced by unfavorable demographic and socioeconomic changes, thus increasing the social and cultural divergence and affecting the local values and ways of living. Consequently, they suffered a major modification and a huge transformation in the concept of rural communities functioning, resulting with high rates of unemployment, mass migrations of productive workforce and unbalanced demographic patterns.

Upon a first-hand experience and after a rapid assessment of the selected rural areas, the research revealed shocking facts. The evaluated villages are literally "dying" due to the rapid decrease in the number of inhabitants. Moreover, since 1948 the population has rapidly decreased in these village for more than $90 \%$. So, it is inevitable for the villages to modify their lifestyle in order to recover, not forgetting that these changes may often be large and long-lasting [10].

Moreover, the study highlights that selected villages have well preserved natural environment, pleasant traditional ambience, authentic food and gastronomic dishes, and stress free environment. They possess many tourism attractiveness, but are facing severe weaknesses for initiating and supporting tourism development as a form for their revival (like: urgent need for modernization of the infrastructure, accommodation capacities, raising awareness of locals for tourism benefits, etc.).

Furthermore, the study urges the need for re-shaping the mindset of locals and implanting a positive attitude towards the concept of rural tourism development keeping in mind that their rural livelihoods possess capabilities, assets (both, material and social resources) as well as activities required for providing basic means of living in rural communities. On the other hand, as found by [6] and [31], the availability of tourist infrastructure does not automatically lead to development of rural areas.

Finally, the research suggests that rural tourism may be a solution for preventing small neglected villages to disappear due to the profound problems of ageing and depopulation. The study argues that sampled villages should follow the experience of the developed countries that emphasized the non-agricultural aspects of sustainable rural development, as the manufacturing industry, indigenous crafts, trade of local products and in particular, practicing rural tourism [9].

\section{Acknowledgement}

This research is part of the project "Evaluation of preconditions for tourism activities in rural depopulated areas - a comparative study between Macedonia and Serbia", carried out by the Academy of Sciences and Arts of the Republic of North Macedonia and the Geographical Institute "Jovan Cvijić" - Belgrade, Serbian Academy of Sciences and Arts.

\section{REFERENCES}

[1] Bærenholdt, J. O., Haldrup, M., Larsen, J., \& Urry, J. Performing Tourist Places. Aldershot, Burlington: Ashgate, 2004.

[2] Beeton, S. Community development through tourism, Landlinks Press, Collingwood, Australia, 2006.

[3] Crouch, D. Tourism, consumption and rurality. In: Cloke, P., Marsden, T., Mooney, P.H. (Eds). Handbook of Rural Studies, (pp. 355-364). London: Sage, 2006. 
[4] Dimitrov, N., \& Petrevska, B. Rural tourism development zones: the case of Macedonia. Researches review of the Department of geography, tourism and hotel management, 41, pp. 152$162,2012$.

[5] Dimitrov, N., Petrevska, B. \& Terzić, A. Rural tourism in the space of NP "Pelister": the case of "Eight Pelister villages", Conference proceedings from the second international scientific conference ISCTBL 2019, Stip, North Macedonia, 13.09.2019, pp. 267-277, 2019.

[6] Dissart, J. C., Vollet, D., Polhes, O., \& Mallebay, M. The landscape: a regional development factor that spurs territory - specific economic flows. In: Cemagref, FR, ${ }^{\text {st }}$ International conference on Landscape Economic, Vienna, 2009.

[7] Dong, E., Wang, Y., Morais, D., \& Brooks, D. Segmenting the rural tourism market: The case of Potter Country, Pennsylvania, USA. Journal of Vacation Marketing, 19(2), pp. 181-193, 2013.

[8] Fredericks, M. Rural Tourism and Economic Development. Economic Development Quarterly, 7, pp. 215-226, 1993.

[9] Đenadić, M., Muhi, B., \& Jovanović, D. Rural tourism - Serbia's missed chance. Economics of Agriculture, 2, pp. 515-529, 2016.

[10] Gaillard, J. Resilience of traditional societies in facing natural hazards. Disaster Prevention and Management: An International Journal, 16(4), pp. 522-544, 2007.

[11] Gašić, M., \& Ivanović, V. Rural tourism in Serbia and impact on economic and social development. In: Thematic proceedings "Modern management tools and economy of tourism sector in present era" (pp. 1-16). Belgrade: Association of Economists and Managers of the Balkans \& Ohrid: Faculty of Tourism and Hospitality, 2018.

[12] Hall, D., Roberts, L., \& Mitchell, M. New Directions in Rural Tourism. Aldershot: Ashgate, 2003.

[13] Hardy, D. Historical Geography and Heritage Studies, Area, 20, pp. 333-338, 1988.

[14] Jepson, D., \& Sharpley, R. More than sense of place? Exploring the emotional dimension of rural tourism experiences. Journal of Sustainable Tourism, 23(8-9), pp. 1157-1178, 2015.

[15] Кънчов, В. Македония. Етнография и статистика, Бугарско книжевно друштво София, 1900.

[16] Kneafsey, M. Tourism, place identities and social relations in the European rural periphery. European Urban and Regional Studies, 7(1), pp. 35-50, 2000.

[17] Lukić, A. Tourism, farm diversification and plurality of rurality: case study of Croatia. European Countryside, 4, pp. 356-376, 2013.

[18] Mak, A., Wong, K. K., \& Chang, R. C. Health or self-indulgence? The motivations and characteristics of spa-goers. International Journal of Tourism Research, 11(2), pp. 185-199, 2009.

[19] Middleton, V. T. C., \& Clarke, J. Marketing in Travel and Tourism. Oxford: Butterworth Heinemann, 2001.

[20] Millar, S. Heritage Management for Heritage Tourism. Tourism Management, 10(3), pp. 9$14,1989$.

[21] Maksimović, M., Urošević, S., \& Damnjanović, Z. Theoretical concepts of rural tourism and opportunities for development in the Republic of Serbia. Economics management information technology, 3, pp. 162-172, 2015.

[22] Nations Online Project: Political Map of Macedonia. Retrieved from https://www.nationsonline. org.

[23] Pedford, J. Seeing is Believing: The Role of Living History in Marketing Local Heritage. In: The Marketing of Tradition, T. Brewer (Ed.), (pp. 13-20). Enfield Lock: Hisarlink Press, 1996. 
[24] Pesonen, J. A., \& Tuohino, A. Rural wellbening tourism destinations - Demand side view. In: Smith, M. K., \& Puczko, L. (Eds). The Routledge Handbook of Health Tourism (pp. 401-418). Routledge, 2016.

[25] Petrevska, B., \& Dimitrov, N. Planning rural tourism development in Macedonia. Journal of Process Management - New Technologies, 1(3), pp. 63-68, 2013.

[26] Petrevska, B., Dimitrov. N. \& Terzić, A. Rural areas in Macedonia as tourism supply: Problem or a challenge? Conference proceedings from the Fourth International conference "Geobalcanica 2019", 15-16.06.2019, Sofia, Bulgaria, pp. 513-518, 2019.

[27] Petrevska, B. \& Terzić, A. Sustainable rural livelihoods: Can tourism related activities contribute? In: Vasile, A. J., Subic, J. Grubor, A., \& Privitera, D. (Eds.) Handbook of Research on Agricultural Policy, Rural Development, and Entrepreneurship in Contemporary Economies, (pp. 354-377), IGI Global: Hershey PA, USA, 2020.

[28] Popescu, A. C. Tourism development in a rural periphery. The case study: the subCarpathians of Oltenians. Journal of Settlements and Spatial Planning, 3, pp. 53-64, 2013.

[29] Ploeg, J. D. The New Peasantries. London: Earthscan, 2008.

[30] Reason, P., \& Bradbury, H. Handbook of action research. London: Sage Publications, 2006.

[31] Sharpley, R. Rural tourism and the challenge of tourism diversification: the case of Cyprus". Tourism Management, 23(3), pp. 233-244, 2002.

[32] State Statistical Office of the Republic of North Macedonia. Official censuses for population and households.

[33] Todorović, M., \& Bjeljac, Ž. Osnove ruralnog turizma u Srbiji (The basis of the rural tourism in Serbia). Bulletin of the Geographical Serbian Society, 87 (1), pp. 135-148, 2007.

[34] Tošić, B. Osnove ruralnog planiranja. Belgrade: Belgrade University, Faculty of Geography, 2011.

[35] Tuohino, A. In search of the sense of Finnish Lakes: a geographical approach to lake tourism marketing. Nordia Geographical Publications, 44(5), pp. 77-77, 2015.

[36] Urry, J. The tourist gaze. London: Thousand Oaks, New Delhi: Sage Publications, 2002.

[37] Weiler, B., \& C., Hall. Special Interest Tourism. London: Belhaven, 1992.

[38] Woods, M. Rural, Milton Park: Routledge, 2010. 